\title{
Exploration of the views of traditional healers regarding the Termination of Pregnancy (TOP) law
}

\author{
MA Rakhudu, MCur \\ University of the North-West, (Mafikeng) \\ AMM Mmelesi, BA Cur Hons \\ University of the North- West, (Mafikeng)
}

CPH Myburgh, HED, BSc Hons, MCom \& DEd

Professor: Faculty of Education, Johannesburg University

M Poggenpoel, RN, PhD

Professor: School of Nursing Science, Faculty of Health Sciences, Johannesburg University

Keywords:

Termination of pregnancy, traditional healers

\section{Correspondence address:}

Prof M Poggenpoel

Department of Nursing Science

Johannesburg University

PO Box 524

AUCKLANDPARK

2006

Tel : (011) 489-2860

Fax : (011) 489-2257

\section{Abstract: Curationis 29(3): 56-60}

The North-West Province is predominantly a rural area, and traditional healers remain the most important and influential members of the rural communities. A qualitative, explorative, descriptive and contextual research design was used. In-depth, individual focused and interactive interviews were held with eight traditional healers from the rural areas of Mmabatho-Mafikeng. In addition, field notes and observations were utilised. The objective of this article is to explore the views of the traditional healers regarding termination of pregnancy (TOP) law. The results reflected the following themes: termination of pregnancy is killing; a child is a precious gift from God and the ancestors; there are alternatives to TOP; people who had any type of abortion should be cleansed with "dipitsa" or herbs; TOP may be allowed only in case of rape and incest, rape and incest offenders should be severely punished; and the traditional healers were not consulted during formulation of the TOP Law.

It is therefore recommended that traditional should be involved in TOP workshops and educational programmes to enable them to provide counselling before and after abortion.

\section{Opsomming}

Die Noordwes Provinsie is ' $n$ hoofsaaklik plattelandse gebied en tradisionele genesers bly die belangrikste en mees invloedryke lede van die plattelandse gemeenskappe. ' $n$ Kwalitatiewe, verkennende, beskrywende en kontekstuele navorsingsontwerp is gebruik. Indiepte, individuele, interaktiewe en fokusonderhoude is met agt tradisionele genesers van die plattelandse gebiede van Mmabatho-Mafikeng gevoer. Voorts is daar van veldnotas en waarnemings gebruik gemaak. Die doelstelling van hierdie artikel is om die menings van die tradisionele genesers in verband met die beeindiging van swangerskap in te win. Uit die resultate het die volgende temas na vore getree: beëindiging van swangerskap is moord; " $n$ kind is ' $n$ waardevolle geskenk van God en die voorvaders, daar is alternatiewe vir die terminering van swangerskap; persone wat enige tipe van aborsie ondergaan het moet met "dipitsa" of kruie skoongemaak word, beëindiging van swangerskap mag slegs in gevalle van verkragting of bloedskande toegelaat word en oortreders van verkragting en bloedskande behoort ernstig gestraf te word; en die tradisionele genesers is nie gedurende die formulering van die Wet op die Beëindiging van Swangerskap geraadpleeg nie. Dit word dus aanbeveel dat 
tradisionele genesers by werkswinkels oor die Beeïndiging van Swangerskap en ander opvoedkundige programme ingesluit moet word om hulle daartoe in staat te stel om berading voor en na aborsie te kan gee.

\section{Introduction}

The North-West Province is $60 \%$ rural. In this region the traditional healers remain the most important and influential members of the rural communities. According to Abdool Karim, Ziqubu and Arendse (1994:14) they are the custodians of the African belief system. The traditional healers were also identified as important components of the South African broader primary health care team (Draft Bill no. 24704, 2003:3). Their views regarding termination of pregnancy (TOP) are crucial, especially in that the government requires community participation in the delivery of the health care services.

Under the previous Act, the Abortion and Sterilisation Act, Act, No. 2 of 1975, abortion was only available for reasons like rape or incest or where there was a substantial risk that the continued pregnancy would pose a threat to the health of the mother or the child or in the case where the child would be severely mentally or physically disabled. This Act did not accommodate any woman with an unwanted pregnancy (Potgieter \& Andrews, 2004: 21).

In the research of Potgieter and Andrews (2004: 25) with 22 TOP providers one of the the participants mentioned many women, irrespective of the contraception they took, had unplanned children which became street children. These women also had backstreet abortions, tried to do the abortion themselves and many died. Approximately 425 women in South Africa died each year in public hospitals because of the complications of unsafe abortion (Rees, Katzenellenbogen, Shabodien, Jewkes, Fawkus, McIntyre, Lombard, Truter \& The National Incomplete Abortion Reference Group, 1997:432-437.

For many years women in African societies have used herbs and other traditional medicine to terminate unwanted pregnancies (Potgieter \& Andrews, 2004: 26).

\section{Problem statement}

From 1 February 1997, the Choice of
Termination of Pregnancy, Act No. 92 of 1996, became a law. The Act allows A woman to request termination of pregnancy without consulting the partner or the parent, in the case of a minor, in the first twelve weeks of pregnancy.

The success of TOP depends on the views of the health workers, the communities and the traditional healers. The essential point here is that the traditional healers form part of the people who may contribute to the success of failure of TOP. They are influential members of the community, thus their opinions are very important. In this research the following research question became relevant:

"What are the views of the traditional healers regarding TOP?"

\section{Objective of the study}

The objective of the study was the following:

- to explore and describe the views of the traditional healers regarding TOP.

\section{Operational definitions}

The following terms are used to convey the meanings of the main concepts in this study:

\section{Traditional healers}

According to Stcyn and Muller (2000:56) traditional healers are diviners guided by their amadlozi (ancestors) and consulted by people of all strata regardless of race, age, gender and level of education. They rely on the bones to make a diagnosis and use herbs for which they were sometimes guided to go and dig in the veld for the ingredients.

\section{Termination of pregnancy (TOP)}

Termination of pregnancy (TOP) refers to the act of bringing a pregnancy to a final end preventing the birth of a live baby. The manual vacuum (MVA) techniques is used mostly DicksonTetteh,1999:20).

\section{World view}

According to the Collins Cobuild English Dictionary for Advanced Learners (2001) a "person's world view is the way they see and understand the world, esoecially regarding issues such as politics, philosophy, and religion".

\section{Measures for trustworthiness}

Strategies to ensure trustworthiness, such as credibility and transferability, were applied (Creswell 1994:167). In achieving credibility the researcher used reflective journals and peer reviews. Literature control was also conducted to verify the results. Transferability was achieved by purposive sampling of traditional healers' in the rural areas. The criteria for inclusion were traditional healers of the rural areas of the NorthWest Province who voluntarily agreed to participate in the research. A description of the methodology, including direct responses of the traditional healers on TOP, is given.

\section{Ethical considerations}

All the participants were informed that the information given would be treated with the strictest confidence. Their names would not be written or used to ensure anonymity. The participants also received the report of the research project.

\section{Research method}

A qualitative, explorative, descriptive and contextual research design was used. Indepth, individual focused interviews were held with the participants in their homes or working places during November - December 1998. The participants were purposefully selected to provide their views regarding TOP. Only eight participants were reviewed because they were the only traditional healers in the rural areas of the NorthWest Province that were willing to participate in the research,

Audiotapes, which were transcribed later, were used. In addition to interactive observation field notes were utilised.

\section{Results}

Eight participants aged from 40 - 75 years, from the rural areas participated. Fifty percent $(n=4)$ were males and the remaining fifty percent were females.

The following themes regarding termination of pregnancy were identified from the traditional healer's views:

- termination of pregnancy is "killing"; a child is a precious gift from God and the ancestors; 
- $\quad$ rape and incest offenders

should be severely punished; and

- traditional healers were not consulted during the formulation of the TOP law.

The themes, including the direct responses of the traditional healers, will now be discussed.

\section{Termination of pregnancy is killing}

Almost all the traditional healers, with the exception of one, were against termination of pregnancy because of moral and religious beliefs. They believed that abortion is murder, or killing a child or a human being:

"According to the Batswana culture and Christian religion, that is killing. We take TOP like killing...".

“... Thousands of our people view abortion as a crime, worse than murder, because they say that by committing abortion, you are killing something which was thousand times more precious than an adult ...".

The results supported the conservative view stated in Olen and Barry (1992:164), that abortion is never morally justifiable. This view is commonly associated with the Roman Catholics, although they are certainly not the only group that espouses it. The view is also in line with what Hord and Xaba (2000: 16), mentioned when they stated that nurses who are against TOP choose not to be trained because abortion is against their religious beliefs.

Poggenpoel, Myburgh and Gmeiner (1998:2) in their study conducted in Gauteng Province indicated that the majority of nurses were of the opinion that the women, as well as the health services delivery staff involved in abortion are murderers.

The traditional healers, nurses and doctors had the same voice regarding TOP:

"Batho ba iphetotse mabitla ka go ntsha dimpa (People have turned themselves

"The government is surprising. It has cancelled death sentence but they kill innocent children. A person has lived, experienced life and committed offences, he is left and not killed, but an innocent child who had never been given a chance to live is killed".

Newburg, head of the South African ProLife Association (Tancred, 1997:36), shares the same sentiments with the traditional healers when he states that the president founded the children's fund, but at the same time denies a number of children life through legal abortion.

\section{A child is a precious gift from God and the ancestors}

The traditional healers perceived a child as a precious gift from God and from the ancestors, and if one terminates pregnancy, one is throwing away the gift:

"Nguana (a child) means a shining being, blessed being. In other words an angel.".

"This is against the ancestors. A baby is a gift from God, so we must be grateful for that. No one is allowed to take away that God had given you".

"If one terminates pregnancy, one is playing with a gift that one was given by God. There are so many people who cannot conceive and on the other hand the government kills babies."

\section{There are alternatives to TOP}

The majority of the participants had one voice on alternatives that are available in the place of TOP. They were of the opinion that such a child should be given to relatives, institutions or agencies that can bring it up. They also reported that preventative measures are freely available.

"There is a Setswana proverb that says 'go botoka go tswala kgoro go nale go bolaya potsana e e ngwegileng' (It is far much better to shut the gate of the kraal than to slaughter the little goat that has managed to escape out)".

"Many African men ask themselves this question, and so do women. Now' that there are things such as condoms and other contraceptives, why the devil do
Smith (1995:132) supports this view by stating that abortions can be avoided through aggressive family planning in South Africa. Poggenpoel, et al (1998:2) state that contraception saves the lives of thousands of women around the world to avoid unwanted pregnancies.

\section{Women who had an abortion of any kind should be cleansed}

Women who had abortions of any kind should be cleansed with herbs Traditional healers spoke in one voice when talking about post-abortion cleansing. They believed that a woman who had an abortion of any kind, be spontaneous or induced, should be cleansed by being given herbs ("dipitsa").

The following statements were made by some of the traditional healers:

". Motho fa a fetetswe kgotsa a senyegetswe o tshwanetse go fin'a dipitsa" (If a person has miscarried or had an abortion, she must be given herbs to cleanse her)".

"If a woman is not given herbs after termination of pregnancy and does not abstain from sexual activity for some time, the man is going to be sick...".

"Like a person who has lost a baby ('a fetetsw'e') she is supposed to take 'dipitsa tsa Setswana' (cultural herbs)".

\section{TOP may be permissible in cases of rape and incest}

The participants were of the opinion that TOP may be done in cases of rape and incest. Some of the participants verbalised this as follows:

"It is understood under certain circumstances, such as rape, and in cases where a person has been pregnated by her father or uncle ...".

'There are always exceptions to the rules. Rape has various consequences. Really, only if there was a clause which says at your choice after rape, and not for everybody who wants to terminate the pregnancy...".

"But nobody who claims to be enlightened or educated should condone a baby born of incest or rape. No, I am sorry. The hospitals must do 
that duty of terminating the pregnancy, but it should be with the consultation of the family...".

\section{Rape and incest offenders should be severely punished}

The traditional healers were angry and unhappy about the rapists and incest offenders. They strongly felt that offenders should be severely punished:

'To have sex with a child or a family member or a relative is ... and such people should be killed".

"'Such offenders should be eliminated from society by killing them...".

"Such offenders are in the increase because the law and society are laxed. They need to be killed...".

The traditional healers echoed the same feelings as many other people, in particular women, as reported almost daily in the media.

\section{Traditional healers were not} consulted during the formulation of the TOP law

Traditional healers were angry and unhappy because they were not consulted when this important law on TOP was formulated. Nurses, as reported by Poggenpoel, et al (1998:4) also voiced this feeling. Traditional healers stated:

"Please understand me and listen carefully. The government may have consulted other people, but we, the traditional healers, were never consulted...".

"You are the first people from the government to come to talk to us about this law...".

This latter statement was verbalised by $87 \%(n=7)$ of the participants.

\section{Brief discussion of the findings}

The findings of this research will now be discussed briefly.

(1) The traditional healers were re prepared to work together with other health workers, and to give input if consulted they were for instance prepared to issue condoms to their clientele in order to make it accessible.
They strongly recommended "dipitsa" (herbs) after any type of abortion, as well as sexual abstinence for a certain period. They believed that most of the problems result from disregarding or undermining traditional values and norms. They for instance associated AIDS with the termination of pregnancy.

They were of the opinion that the public should be educated on procedures to be followed when raped, so as to be helped as soon as possible.

Most of the traditional healers indicated that there are certain traditional healers who are positive about TOP and have been doing it before it was legalised.

Some traditional healers were of the opinion that the law also expects them to perform TOP.

\section{Conclusions and}

\section{recommendations}

From the interviews it was evident that the traditional healers, were not in favour of TOP because of moral and religious grounds and social values. Traditional healers perceived TOP as murder and preventive measures and alternatives such as adoption and foster care should be utilised.

Traditional healers reckon that they should have been consulted during the formulation of the TOP law. They also are of the opinion that rape and incest offenders should be severely punished by law.

Based on the above conclusions the following recommendations are made:

Since $80 \%$ of black patients rather consult traditional healers before visiting Western doctors (Abdool Karim, et al (1994: 14) this untapped resource should be empowered through infrastructure, equipment and material (Steyn and Muller, 2000:8). During the implementation of educational programmes ands TOP workshops, traditional healers should be involved, especially during value clarification workshops, because this will enable them to provide counselling before and after abortion. New things are not accepted easily, even contraceptives were not accepted easily by traditional healers initially, but now these are acceptable.

\section{List of references}

ABDOOL KARIM, SS; ZIQUBU, T \& ARENDSE, R 1994. Potential health care partnership between African healers and biomedical personnel in South Africa. South African Medical Journal. Dec (Insert); 84 (12): 14-15.

ANONYMOUS. 1998. Traditional healers and TOP. Drum. Nov. 1998: 5.

BURNS, N \& GROVE, SK 1993. The practice of nursing research: Conduct, critique and utilisation. Philadelphia: Saunders.

COLLINS COBUILD ENGLISH DICTIONARY FOR ADVANCED LEARNERS. 2001. Birmingham: Harper Collins.

CRESWELL, JW 1994. Research design. Qualitative and quantitative approaches. London: Sage.

DICKSON-TETTEH, K 1999. The national abortion care programme. Health and Hygiene, 10 (5): 20-22.

DRAFT BILL NO. 24704, 2003. Traditional Health Pracxtitioners Bill (In: Government Gazette, RSA, 11 April 2003. Volume 4354. Pretoria: Government Printer.

OLEN, J \& BARRY, V 1992. Applying ethics: A text with readings. Belmont: Wadsworth.

POGGENPOEL, M; MYBURGH CPH \& GMEINER, AC 1998. One voice regarding legislation of abortion. Curationis. 21 (3), 2-7.

POTGIETER,M \& ANDREWS, G 2004. South African nurses' accounts for choosing to termination of pregnancy providers. Health SA Gesondheid, 9 (2): 20-30.

REES, H; KATZENELLENBOGEN, J; SHABODIEN, R; JEWKES, R; FAWKUS, S; MCINTYRE, J; LOMBARD, C; TRUTER, H \& THE NATIONAL INCOMPLETE ABORTION REFERENCE GROUP 1997. The epidemiology of incomplete abortion in South Africa. South African Medical Jourrnal. 87 (4): 432-437.

SMITH, J 1995. Abortion - a debate. 
South African Medical Journal. 85 (3): 139-160.

SOUTH AFRICA 1975. Abortion and Sterilisation Act., No. 2 of 1975. Pretoria: Government Printer.

SOUTH AFRICA 1996. Act No 92 of 1996. The choice on termination of pregnancy. Pretoria: Government Printer.

SOUTH AFRICA 1997. Health Bill. Act No. of 1997. Pretoria: Government Printer.

STEYN, M \& MULLER, A 2000. Traditional healers and cancer prevention. Curationis. September 2000, 23(3): 4-11.

TANCRED, E 1997. Aborsie, die nuwe feite. Rooi Rose. Junie 1997:34-36. 